\title{
Evaluation of Factors Affecting Emergence Agitation in Pediatric Anesthesia Practice
}

\author{
Gökhan Uğur, Elif Bombacı, Banu Çevik
}

Department of Anesthesiology and Reanimation, Kartal Dr. Lütfi Kırdar Training and Research Hospital, İstanbul, Turkey

Submitted: 27.03.2018 Accepted: 16.04.2018

Correspondence: Elif Bombacı, Denizer Cad., Kartal Dr. Lütfi Kırdar Eğitim ve Araştırma Hastanesi, Cevizli, Kartal, İstanbul, Turkey E-mail:bombaciel@yahoo.com

arya

Keywords: Anesthesia; emergence agitation; pediatric.

\begin{abstract}
Objective: The agitation that is sometimes seen in children during the recovery period after the administration of anesthesia can be a difficult problem to solve, and can turn a successful procedure into a distressing situation. This prospective, observational study was intended to determine factors that may lead to postoperative agitation in children in order to contribute to future pediatric anesthesia studies.
\end{abstract}

Methods: A total of 206 patients between 3 and 10 years of age who underwent operations performed by the departments of orthopedics and traumatology; urology; eye diseases; ear, nose, and throat diseases; pediatric surgery; and plastic and reconstructive surgery and whose physical status was classified as American Society of Anaesthesiologists I or II were included in the study. The patients' age, gender, details of preoperative fasting, previous surgeries (if any), premedication used (if any) and the method of application, the induction technique and drug used for anesthesia, airway management method, drugs used to maintain anesthesia and duration, postoperative analgesic management, and the duration of stay in the recovery room were recorded. In addition, the Face, Legs, Activity, Cry, Consolability score; the Pediatric Anesthesia Emergence Delirium score; and the modified Aldrete score recorded at the postoperative $10^{\text {th }}$ minute were analyzed.

Results: Statistical evaluation revealed that age, operation type, anesthesia technique and drug selected, airway management method, drug used for induction and maintenance of anesthesia, and the duration of anesthesia significantly affected postoperative agitation $(p<0.05)$. Regression analysis determined that patient age and the drug selected for the induction and the maintenance of anesthesia were independent risk factors for agitation developing during the recovery period.

Conclusion: The age of the child, the duration of anesthesia, and the preferred anesthesia induction technique were the primary factors affecting agitation seen in children during recovery from anesthesia. Since the age of the patient and the duration of the surgery and anesthesia are factors that it is difficult or impossible to change, the anesthesia induction technique to be used is an important tool for the anesthesiologist to control the development of agitation during the recovery period.

\section{INTRODUCTION}

Emergence agitation is a clinical condition characterized by various symptoms, including behavioral disorders, fatigue, sobbing, and disorientation. ${ }^{[l]}$ The agitation experienced by a child during the recovery period after surgery may be dangerous: the child may scream and cry, unconsciously try to stand up, move their head violently, pull at the wound site, or attempt to pull out drains and catheters.
Sometimes, drug treatment may be required. This condition may lead to a prolongation of recovery and delay discharge. It will also increase the worry and anxiety of the parents. Most of the investigations directed at the etiology of agitation observed during the recovery period have compared the effectiveness of anesthetic drugs used to relieve emergence agitation. However, an examination of etiological agents requires looking at more than medications used. 
In this prospective observational study, the objective was to determine risk factors for agitation observed in children during the transition from unconsciousness to wakefulness following the administration of anesthesia, and to investigate protocols to prevent postoperative agitation.

\section{MATERIAL AND METHODS}

This prospective, observational study was performed in the clinic of anesthesiology and reanimation of the hospital after obtaining the approval of the ethics committee of Kartal Dr. Lütfi Kırdar Education and Research Hospital (date: October 24, 2017; decision no.: 2017/5/4/I 16/4). Pediatric patients aged between 3 and 10 years with a physical status of American Society of Anaesthesiologists (ASA) classification I or II who underwent surgery performed in the clinics of orthopedics and traumatology; urology; eye diseases; ear, nose, and throat diseases; pediatric surgery; and plastic and reconstructive surgery between May 2017 and August 2017 were included in the study. A researcher observer in the recovery room evaluated the patients and recorded data regarding patient age, gender, type of surgery, previous surgeries (if any), any drug used for premedication and its method of administration, the anesthesia induction technique and drugs used for induction, the airway management method, drugs used for the maintenance of anesthesia, the duration of anesthesia, drugs used to provide analgesia, and the method of their administration. Information related to anesthesia was gathered from anesthesia monitoring forms, and when necessary, from the anesthesia team, and the preoperative evaluation form was used to collect information about any previous surgery. Information about preop- erative fasting was obtained from the parents of the patient or the attendant clinicians.

Once a modified Aldrete score (MAS) of $\geq 9$ was obtained after surgery, the patient was transferred to service, and the length of their recovery room stay, and 10 -minute-postoperative Face, Legs, Activity, Cry, Consolability (FLACC) pain (Table I), Pediatric Anesthesia Emergence Delirium (PAED) (Table 2), and MAS (Table 3) scores were recorded.

IBM SPSS Statistics for Windows, Version 22.0 (IBM Corp., Armonk, NY, USA) was used to conduct the statistical analyses. The Student's t-test was used for pairwise intergroup comparisons of descriptive statistical parameters (mean, standard deviation, minimum and maximum), and a one-way analysis of variance was used for multiple comparisons. Statistical significance was accepted as $p<0.05$. Regression analysis was performed to evaluate independent risk factors.

\section{RESULTS}

A total of 206 pediatric patients aged 3 to 10 years with a physical status of ASA I or II who underwent surgery performed in the operating rooms of the clinics of orthopedics and traumatology; urology; eye diseases; ear, nose, and throat diseases; pediatric surgery; and plastic and reconstructive surgery between May 2017 and August 2017 were included in the study.

Of the study group, $80 \%$ of the patients were male. Anamneses revealed that $22.8 \%$ of the patients had previously undergone surgery. The median preoperative fasting period was 8.3 hours. Premedication was applied in $35.9 \%$ of

Table I. Pediatric Anesthesia Emergence Delirium scale

\begin{tabular}{|c|c|c|c|c|c|}
\hline Behavior & Not at all & Just a little & Quite a bit & Very much & Extremely \\
\hline Makes eye contact with caregiver & 4 & 3 & 2 & I & 0 \\
\hline Actions are purposeful & 4 & 3 & 2 & I & 0 \\
\hline Aware of surroundings & 4 & 3 & 2 & 1 & 0 \\
\hline Restless & 0 & 1 & 2 & 3 & 4 \\
\hline Inconsolable & 0 & 1 & 2 & 3 & 4 \\
\hline
\end{tabular}

Table 2. Face, Legs, Activity, Cry, Consolability pain scale

\begin{tabular}{llll}
\hline Category & $\mathbf{0}$ & $\mathbf{I}$ & $\mathbf{2}$ \\
\hline Face & No particular expression & Grimace or frown, withdrawn & Frown, clenched jaw \\
Legs & Normal position or relaxed & Tense, restless, uneasy & Kicking or legs drawn up \\
Activity & Lying quietly & Shifting back and forth, squirming & Arched, rigid, or jerking \\
Cry & No crying & Moaning, whimpering & Crying steadily, screaming, complaining \\
Consolability & Relaxed & Reassured by touching, hugging & Difficult to console or comfort \\
\hline
\end{tabular}


Table 3. Modified Aldrete scale

\begin{tabular}{|c|c|c|c|}
\hline \multirow[t]{3}{*}{ Respiration } & 2 & I & 0 \\
\hline & Ability to take deep & Dyspnea, shallow and & Apnea \\
\hline & breath or cough & restricted breathing & \\
\hline \multirow[t]{3}{*}{ Oxygen saturation } & 2 & I & 0 \\
\hline & Maintains $>92 \%$ on room air & Needs oxygen inhalation to & Saturation $<90 \%$ even with \\
\hline & & maintain saturation of $>90 \%$ & supplemental oxygen \\
\hline \multirow[t]{2}{*}{ Consciousness } & 2 & I & 0 \\
\hline & Fully awake & Arousable on calling & Not responsive \\
\hline \multirow[t]{2}{*}{ Circulation } & 2 & 1 & 0 \\
\hline & $\mathrm{BP} \pm 20 \mathrm{mmHg}$ preoperative & $\mathrm{BP} \pm 20-50 \mathrm{mmHg}$ preoperative & $\mathrm{BP} \pm 50 \mathrm{mmHg}$ preoperative \\
\hline \multirow[t]{3}{*}{ Activity } & 2 & I & 0 \\
\hline & Able to move 4 extremities & Able to move 2 extremities & Able to move 0 extremities \\
\hline & voluntarily or on command & voluntarily or on command & voluntarily or on command \\
\hline
\end{tabular}

Table 4. Descriptive statistical data

\begin{tabular}{lc}
\hline (Minimum-maximum) & Mean \pm SD \\
\hline Age (3-10 years) & $6.28 \pm 2.29$ \\
Body weight (10-50 kg) & $24.78 \pm 8.11$ \\
Duration of fasting (5-14 hours) & $8.3 \pm 1.99$ \\
Duration of anesthesia (10-150 minutes) & $39.08 \pm 24.13$ \\
Recovery room stay (I0-45 minutes) & $18.86 \pm 7.57$ \\
FLACC Score (0-10) & $3.12 \pm 2.98$ \\
PAED Score (0-16) & $7.91 \pm 4.06$ \\
Modified Aldrete scale Score (7-10) & $9.63 \pm 0.60$ \\
\hline & $\mathbf{n} / \mathbf{n}(\% / \%)$ \\
\hline Gender (male/female) & $166 / 40(80.6 / 19.4)$ \\
Previous surgery (yes/no) & $47 / 159(22.8 / 77.2)$ \\
Premedication (yes/no) & $74 / 132(35.9 / 64.1)$ \\
Analgesia (yes/no) & $196 / 10(95.6 / 4.4)$
\end{tabular}

FLACC: Face, Legs, Activity, Cry, Consolability pain scale; PAED: Pediatric Anesthesia Emergence Delirium scale; SD: Standard deviation. the cases. The minimum and maximum duration of anesthesia was 10 minutes and 150 minutes, respectively. Postoperative analgesia was provided for $95.6 \%$ of the patients. The median duration of recovery room stay was 18.86 minutes (Table 4).

\section{Correlations between age and FLACC, PAED, and MAS}

The patients were divided into 3 groups when evaluating the correlation between age and the 10-minute-postoperative FLACC, PAED, and MAS: the groups were defined as those aged $<6,6$ to 10 , and 10 years. The highest and the lowest FLACC and PAED scores were detected in patients aged $<6$ and 10 years, respectively. The MAS at 10 minutes was similar in all 3 age groups (Table 5).

\section{Correlation between the type of surgery and FLACC, PAED, and MAS}

The lowest and highest mean FLACC and PAED scores were found in patients who underwent pediatric and orthopedic surgery, respectively. Statistical evaluation revealed that the type of surgery performed significantly af-

Table 5. Correlation between age group and FLACC, PAED, and MAS

\begin{tabular}{lcccc}
\hline Age (years) & Patients $(\mathbf{n})$ & FLACC score (Mean \pm SD) & PAED score (Mean \pm SD) & MAS score (Mean \pm SD) \\
\hline$<6$ & 86 & $3.95 \pm 3.03$ & $9.65 \pm 3.86$ & $9.59 \pm 0.68$ \\
$6-10$ & 97 & $2.78 \pm 2.93$ & $7.01 \pm 3.77$ & $9.62 \pm 0.55$ \\
10 & 23 & $1.43 \pm 1.90$ & $5.22 \pm 3.29$ & $9.83 \pm 0.49$ \\
P value & 206 & $<0.01$ & $<0.01$ & 0.25 \\
\hline
\end{tabular}

P $<0.05$ was considered statistically significant; one-way analysis of variance. FLACC: Face, Legs, Activity, Cry, Consolability pain scale; MAS: Modified Aldrete scale PAED: Pediatric Anesthesia Emergence Delirium scale; SD Standard deviation. 
fected the FLACC and PAED scores. The MAS measured at 10 minutes was similar in the 3 groups (Table 6).

Correlation between method of premedication and FLACC, PAED, and MAS

The drugs used for premedication were examined in 4 groups: oral ketamine + midazolam, intravenous (IV) midazolam, midazolam per oral (PO), and no premedication. Most $(n=|3|)$ of the patients did not receive premedication, while 3 patients were given midazolam PO. The highest and the lowest FLACC scores were detected in the oral midazolam and the ketamine + midazolam groups, respectively. A statistically significant difference was detected between groups. A similar, but statistically insignificant, correlation was also found between the drug used for premedication and PAED scores. The lowest and highest MAS were detected in the oral midazolam and the ketamine + midazolam oral groups, respectively, with a statistically significant intergroup difference (Table 7).

Correlation between airway management and anesthesia induction technique and FLACC, PAED, and MAS

Three airway management methods were used: endotracheal intubation, laryngeal mask airway, and facemask.
There was a statistically significant difference in the mean FLACC, PAED, and MAS in the facemask-group.

The patients were evaluated in 4 groups according to the anesthetic drug and technique used: propofol + ketamine, propofol, sevoflurane, and thiopental groups. The FLACC and PAED scores were markedly lower in the propofol + ketamine group, and they were highest in the thiopental group, with a significant intergroup difference. The MAS scores were significantly lower in the propofol + ketamine group (Table 8).

Correlation between anesthetic agent used for maintenance of anesthesia and duration of anesthesia and FLACC, PAED, and MAS

Desflurane, propofol, and sevoflurane were used to maintain anesthesia in our patients. In all, 36 patients were not administered any drug apart from those used for induction as a result of a shorter operative time. The patients were divided into 4 groups. The highest mean FLACC and PAED scores were detected in the desflurane group, while the FLACC scores were lower in the propofol group compared with patients who received other anesthetic drugs. The PAED scores were similar between the propofol and the sevoflurane groups, while the lowest FLACC and PAED scores were detected in the group that did not

Table 6. Correlation between type of surgery and FLACC, PAED, and Modified Aldrete Scores

\begin{tabular}{lcccc}
\hline Type of surgery & Patients $(\mathbf{n})$ & FLACC score (Mean \pm SD) & PAED score (Mean \pm SD) & MAS score (Mean \pm SD) \\
\hline Pediatric surgery & 118 & $2.35 \pm 2.58$ & $7.07 \pm 3.74$ & $9.53 \pm 0.69$ \\
Ophthalmology & 10 & $4.30 \pm 2.58$ & $9.90 \pm 3.35$ & $9.70 \pm 0.48$ \\
Ear, nose, throat & 35 & $3.77 \pm 2.94$ & $8.74 \pm 4.13$ & $9.71 \pm 0.46$ \\
Orthopedics & 12 & $6.25 \pm 3.22$ & $10.67 \pm 3.50$ & $9.75 \pm 0.45$ \\
Reconstructive surgery & 13 & $4.38 \pm 3.64$ & $9.77 \pm 4.99$ & $9.85 \pm 0.38$ \\
Urology & 18 & $3.28 \pm 3.21$ & $7.56 \pm 4.48$ & $9.89 \pm 0.32$ \\
P value & 206 & $<0.01$ & $<0.01$ & 0.08 \\
\hline
\end{tabular}

P $<0.05$ was considered statistically significant; one-way analysis of variance. FLACC: Face, Legs, Activity, Cry, Consolability pain scale; MAS: Modified Aldrete scale PAED: Pediatric Anesthesia Emergence Delirium scale; SD: Standard deviation.

Table 7. Correlation between drugs used for premedication and FLACC, PAED, and MAS

\begin{tabular}{|c|c|c|c|c|}
\hline Premedication & Patients (n) & FLACC score (Mean \pm SD) & PAED score (Mean $\pm S D)$ & MAS score (Mean $\pm S D)$ \\
\hline Ketamine+midazolam oral & 32 & $2.19 \pm 2.68$ & $7.50 \pm 3.72$ & $9.06 \pm 0.91$ \\
\hline Midazolam intravenous & 40 & $4.00 \pm 3.42$ & $9.00 \pm 4.37$ & $9.73 \pm 0.45$ \\
\hline Midazolam oral & 3 & $6.33 \pm 0.58$ & $11.67 \pm 1.53$ & $10.00 \pm 0.00$ \\
\hline None & $13 \mid$ & $3.0 I \pm 2.84$ & $7.60 \pm 4.01$ & $9.73 \pm 0.46$ \\
\hline$P$ value & & 0.02 & 0.09 & $<0.01$ \\
\hline
\end{tabular}

$\mathrm{P}<0.05$ was considered statistically significant; one-way analysis of variance. FLACC: Face, Legs, Activity, Cry, Consolability pain scale; MAS: Modified Aldrete scale PAED: Pediatric Anesthesia Emergence Delirium scale; SD: Standard deviation. 
receive any drug for maintenance of anesthesia. The MAS were significantly lower in the group that did not receive any drug for maintenance of anesthesia.

Three groups were formed to examine the duration of anesthesia (DA): DA $<30$ minutes, $30-60$ minutes, and $\geq 60$ minutes. The lowest and highest mean FLACC, PAED, and MAS were detected in the groups of $D A<30$ minutes and $\geq 60$ minutes, respectively. A statistically significant difference was detected between groups. Increases in FLACC, PAED, and MAS were observed in parallel with increases in the duration of anesthesia (Table 9).

Correlation between the management of postoperative analgesia and FLACC, PAED, and MAS

The patients were allocated into 9 groups with respect to the method used to provide postoperative analgesia: fentanyl, paracetamol, fentanyl + paracetamol, caudal block, penile block, penile block + fentanyl, penile block + paracetamol, tramadol, and a group that did not receive postoperative analgesia.

The lowest mean FLACC scale score was seen in the caudal block group, while the lowest PAED score was observed in the penile block + fentanyl group. The highest FLACC, PAED, and MAS were in the penile block + paracetamol group. Statistical evaluation revealed that the method of analgesia management created a significant difference in pain, agitation, and recovery (Table 10).

Gender, history of previous surgery, and fasting period did not create a significant difference in terms of FLACC, PAED, and MAS in our study $(p>0.05)$.

The impact of independent risk factors on FLACC score

Regression analysis revealed that the duration of anesthe-

Table 8. Correlation between airway management and induction of anesthesia and FLACC, PAED, and MAS

\begin{tabular}{lcccc}
\hline Airway & Patients (n) & FLACC score (Mean \pm SD) & PAED score (Mean \pm SD) & MAS score (Mean \pm SD) \\
\hline Intubation & 57 & $4.49 \pm 3.31$ & $9.25 \pm 4.51$ & $9.81 \pm 0.40$ \\
Laryngeal mask airway & $1 \mathrm{II}$ & $3.23 \pm 2.73$ & $7.89 \pm 3.92$ & $9.69 \pm 0.54$ \\
Mask & 38 & $0.76 \pm 1.36$ & $5.97 \pm 2.88$ & $9.18 \pm 0.80$ \\
Propofol + ketamine & 38 & $0.68 \pm 1.07$ & $6.03 \pm 2.78$ & $9.13 \pm 0.78$ \\
Propofol & 77 & $2.92 \pm 2.83$ & $6.87 \pm 3.93$ & $9.77 \pm 0.51$ \\
Sevoflurane & 39 & $4.23 \pm 3.00$ & $9.15 \pm 4.39$ & $9.77 \pm 0.48$ \\
Thiopental & 52 & $4.37 \pm 3.03$ & $9.90 \pm 3.71$ & $9.69 \pm 0.47$ \\
P value & & $<0.01$ & $<0.01$ & $<0.01$ \\
\hline
\end{tabular}

P $<0.05$ was considered statistically significant; one-way analysis of variance. FLACC: Face, Legs, Activity, Cry, Consolability pain scale; MAS: Modified Aldrete scale PAED: Pediatric Anesthesia Emergence Delirium scale; SD: Standard deviation.

Table 9. Correlation between agent used to maintain anesthesia and duration of anesthesia and FLACC, PAED, and MAS

\begin{tabular}{lcccc}
\hline Anesthetic & Patients $(\mathbf{n})$ & FLACC score (Mean \pm SD) & PAED score (Mean \pm SD) & MAS score (Mean \pm SD) \\
\hline Desflurane & 29 & $4.38 \pm 3.08$ & $9.17 \pm 4.29$ & $9.76 \pm 0.44$ \\
Propofol & 6 & $2.83 \pm 3.37$ & $8.17 \pm 3.31$ & $9.50 \pm 0.55$ \\
Sevoflurane & 135 & $3.53 \pm 2.95$ & $8.16 \pm 4.18$ & $9.74 \pm 0.50$ \\
None & 36 & $0.64 \pm 1.07$ & $5.94 \pm 2.84$ & $9.14 \pm 0.80$ \\
P value & 206 & $<0.01$ & 0.01 & $<0.01$ \\
Duration of anesthesia & & & & $9.76 \pm 0.43$ \\
(minutes) & & & & $9.70 \pm 0.55$ \\
$\quad \geq 60$ & 50 & $4.88 \pm 3.18$ & $9.82 \pm 4.03$ & $9.51 \pm 0.69$ \\
$\quad 30-60$ & 64 & $3.06 \pm 2.91$ & $7.55 \pm 4.19$ & 0.03 \\
\hline 30 & 92 & $2.21 \pm 2.48$ & $7.13 \pm 3.68$ & $<0.01$ \\
\hline
\end{tabular}

P $<0.05$ was considered statistically significant; one-way analysis of variance. FLACC: Face, Legs, Activity, Cry, Consolability pain scale; MAS: Modified Aldrete scale PAED: Pediatric Anesthesia Emergence Delirium scale; SD: Standard deviation. 
Table 10. Correlation between postoperative analgesia management and FLACC, PAED, and MAS

\begin{tabular}{|c|c|c|c|c|}
\hline Analgesia management & Patients (n) & FLACC score (Mean $\pm S D)$ & PAED score (Mean $\pm S D)$ & MAS score (Mean $\pm S D)$ \\
\hline Fentanyl & 13 & $3.46 \pm 2.30$ & $7.38 \pm 4.54$ & $9.77 \pm 0.44$ \\
\hline Fentanyl+paracetamol & 48 & $4.15 \pm 3.07$ & $8.94 \pm 3.73$ & $9.67 \pm 0.48$ \\
\hline Caudal block & 9 & $0.44 \pm 0.53$ & $4.44 \pm 1.67$ & $9.78 \pm 0.44$ \\
\hline Paracetamol & 46 & $4.35 \pm 3.10$ & $9.80 \pm 4.09$ & $9.85 \pm 0.36$ \\
\hline Penile block & 43 & $1.53 \pm 2.54$ & $6.30 \pm 3.29$ & $9.26 \pm 0.76$ \\
\hline Penile block+fentanyl & 5 & $1.20 \pm 1.30$ & $4.20 \pm 2.95$ & $9.60 \pm 0.55$ \\
\hline Penile block+paracetamol & 15 & $5.07 \pm 2.52$ & $10.93 \pm 3.77$ & $9.87 \pm 0.52$ \\
\hline Tramadol & 14 & $1.93 \pm 1.64$ & $5.07 \pm 1.90$ & $9.79 \pm 0.43$ \\
\hline None & 9 & $1.89 \pm 2.52$ & $7.56 \pm 4.28$ & $9.77 \pm 1.00$ \\
\hline$P$ value & & $<0.01$ & $<0.01$ & $<0.01$ \\
\hline
\end{tabular}

p $<0.05$ was considered statistically significant; one-way analysis of variance. FLACC: Face, Legs, Activity, Cry, Consolability pain scale; MAS: Modified Aldrete scale PAED: Pediatric Anesthesia Emergence Delirium scale; SD: Standard deviation.

sia was the most important independent risk factor affecting the FLACC score, as well as age, duration of anesthesia, and the drug used for induction. Similarly, age and the drug used for induction were individual risk factors affecting the PAED score.

\section{DISCUSSION}

In pediatric anesthesia, as in all applications of anesthesia, the ideal is to prevent anxiety in the preoperative period and to provide a comfortable perioperative and postoperative period. However, despite the application of premedication, significant pre- and postoperative agitation may be seen in pediatric patients, and the resolution of postoperative agitation is complicated. This condition can frighten and worry the parents, and result in significant efforts and demands on the time of the anesthesia and surgical teams. Sikich and Lerman ${ }^{[2]}$ described emergence delirium in children as impaired awareness of surroundings, changes in perception, and disorientation.

As expected, small children may become more severely agitated, since they are more dependent on their parents, have a lower tolerance for fasting, less flexibility with strange settings, and a lower pain threshold. Agitation in children with better cooperation skills can be kept under control more easily. In our study, the PAED and FLACC scores were significantly higher in children aged less than 6 years of age, and significantly lower in patients aged less than 10 years. In their risk evaluation, Hino et al. ${ }^{[3]}$ found that demographic characteristics including age, height, and body weight were highly correlated with the frequency of emergence agitation, and among these parameters, age, in particular, was demonstrated to be an independent risk factor for emergence agitation. Bergmans et al. ${ }^{[4]}$ evaluated postoperative agitation in 343 patients aged I.5 to 5 years and 6 to 18 years using PAED scale scores, and found significantly higher levels of postoperative agitation in younger children. In our study, regression analysis indicated that age was an independent risk factor in the development of postoperative agitation. Easier communication with older children and the ability to inform the patient directly about the procedures to be performed helps to reduce the problem.

In a study conducted by Bergmans et al.," ${ }^{[4]}$ significantly higher PAED scale scores were found in patients without a history of surgery. Similarly, in our study, the PAED scores were lower in patients with a previous history of surgery, though without a statistically significant intergroup difference. Based on these results, it was thought that a previous experience of surgery decreased the incidence of postoperative agitation and delirium, and accelerated the process of recovery.

The choice between intravenous and inhalation anesthesia in pediatric patients varies according to age, patient compliance, the availability of venous access, the preferred method of airway management, and the extent of surgical intervention. In our study, variations in postoperative agitation scores were observed based on the anesthetic agent preferred for the induction of anesthesia. The lowest and the highest FLACC and PAED scores were detected in the ketamine + propofol group and the thiopental group, respectively, with a significant intergroup difference. This can be attributed to the analgesic characteristics of ketamine and a prolonged recovery period. In support of this finding, the lowest MAS scores were detected in the propofol + ketamine group, and the highest scores were seen in the sevoflurane and propofol alone groups, with a significant intergroup difference.

Son et al. ${ }^{[5]}$ reported that in pediatric patients aged 3 to 7 years, intravenous induction of anesthesia with thiopental 
decreased the frequency of postoperative agitation during immediate recovery period compared with inhalation anesthesia with sevoflurane. However, in our study, we observed that induction of anesthesia with thiopental or sevoflurane significantly increased postoperative agitation when compared with induction of anesthesia using propofol or propofol + ketamine. It is known that sevoflurane is the most frequent culprit agent in pediatric cases with postoperative agitation. ${ }^{[6-8]}$ As reported by Son et al., induction of anesthesia with thiopental may decrease the frequency of postoperative agitation when compared with sevoflurane; however, a combination of propofol and ketamine may be the most effective.

In our study, pain and agitation scores were significantly lower in the 36 patients (17.6\%) who had a surgery of shorter duration and who did not require an additional dose of medication to maintain anesthesia. Notably, the postoperative FLACC scores were significantly lower in cases that received propofol for the maintenance of anesthesia, while PAED scores were significantly higher in patients who received desflurane to maintain anesthesia. The highest 10-minute MAS was seen in the desflurane group. Sezen et al. ${ }^{[9]}$ compared the effects of desflurane and propofol on postoperative recovery in 40 patients aged 4 to 12 years who had undergone a tonsillectomy or an adenotonsillectomy, and they reported a faster recovery with propofol compared with total intravenous anesthesia. Ahrazoğlu et al. ${ }^{[7]}$ investigated the effects of desflurane and sevoflurane on postoperative agitation in a total of 42 patients, and found that desflurane led to a faster recovery, though without a significant intergroup difference.

In a meta-analysis, Guo et al. ${ }^{[10]}$ investigated the effects of propofol, desflurane, halothane, isoflurane, and sevoflurane on agitation and recovery in pediatric cases, and recommended propofol as the most effective and safest anesthetic agent to provide pediatric anesthesia. Desflurane was reported to have the greatest incidence of agitation and the most difficult recovery characteristics. Based on our results and the findings of all these studies, it may be concluded that while in most cases, the rapid clearance of desflurane from the body after the termination of anesthesia and a shorter recovery period are advantages of this drug, given other factors affecting the development of postoperative agitation in children, it may be a disadvantage in some cases.

When invasive airway management methods are used, emergence agitation is often related to triggering factors, such as a sore throat, edema, spasms, or dyspnea. In our study, the postoperative PAED and FLACC scores were significantly higher in patients who had endotracheal intubation, and the scores were lower in cases where facemasks were used. However, it should be kept in mind that facemasks were used for shorter, less intense surgeries.
The invasiveness of the intervention, the presence of a urinary catheter, nasogastric tube, eye ointment or pads, or a nasal tamponade is closely associated with postoperative agitation. As a result of the relatively intense surgical stress and postoperative pain, as well as the application of splints and casts that restrict the patient's mobility and may cause uneasiness, higher postoperative agitation scores are anticipated in orthopedic interventions. Joo et al. ${ }^{\left[{ }^{\prime \prime}\right]}$ examined the postoperative emergence delirium and the invasiveness of the surgical method applied in 90 patients aged 2 to 5 years who had undergone strabismus surgery, and demonstrated an increased incidence and severity of emergence delirium in patients who had undergone complicated strabismus surgery relative to those who had had simpler surgical procedures. In a study by Hino et al., ${ }^{[3]}$ the authors revealed that younger age, longer duration of anesthesia, and the surgical procedure performed were determinative risk factors in the development of agitation. Anesthesia for longer than I hour, and strabismus surgery and tonsillectomy procedures were determined to be risk factors for postoperative agitation. In our study, a significantly higher PAED and FLACC score was seen in the orthopedic patients who underwent surgical interventions involving the bone and connective tissue, which tends to support this opinion. In the present study, most of the operations performed by pediatric surgeons were small surgical interventions, such as circumcision or inguinal hernia repair, performed under one-day anesthesia. Therefore, the PAED and FLACC scores in this patient group were significantly lower.

One of the most important causes of postoperative agitation is pain. In our clinic, various drugs are used to provide postoperative analgesia. Fentanyl is typically used for perioperative analgesic support rather than postoperative pain. In cases of a short surgical intervention, generally, no other additional analgesic drug is used, or, if required, paracetamol is preferred in these cases for its mild effect.

In our study, the highest agitation scores were seen in patients who were given only paracetamol as an analgesic. The postoperative PAED and FLACC scores were significantly higher in patients who had a penile block and paracetamol to relieve pain. This result may have been associated with an ineffective application of the penile block, perineural edema, or tension caused by the local anesthetic agent during the early postoperative period and the reduced analgesic potency of paracetamol. The inadequate response rates in cases of a penile block may also be attributed to the very small, dorsal penile nerve, which cannot be visualized easily on ultrasonograms. ${ }^{[12]}$ In a study performed with 260 patients, Roberts et al. ${ }^{[13]}$ demonstrated that despite the minimal side effects of an intraoperatively administered, single dose of IV paracetamol, the addition of a single IV dose of paracetamol to standard narcotic and non-narcotic analgesics did not provide a sta- 
tistically significant improvement in pain control. Jung et al. ${ }^{[14]}$ demonstrated that IV fentanyl in doses of $1.5 \mu \mathrm{g} \mathrm{kg}^{-1}$ decreased postoperative agitation without prolonging the recovery period, and no significant correlation was found between preoperative anxiety and postoperative agitation. The results of their study support our results.

\section{CONCLUSION}

According to the results of our research and similar studies, among the factors affecting the risk for emergence agitation and delirium during the application of pediatric anesthesia, the child's age, the duration of anesthesia, and the induction technique are most important. Since it is often impossible to limit the indications for surgery in children according to age, decreasing the duration of surgery and anesthesia, and using minimally invasive methods and materials and an intravenous anesthesia induction technique instead of mask induction as much as possible can prevent or reduce agitation in the postoperative period in pediatric patients. We believe that preventing or at least decreasing postoperative pain is an important step in controlling emergence agitation.

Ethics Committee Approval

Kartal Dr. Lütfi Kırdar Education and Research Hospital (date: October 24, 2017; decision no.: 2017/5 I4/I I6/4).

Peer-review

Internally peer-reviewed.

Authorship Contributions

Concept: E.B., B.Ç., G.U.; Design: E.B., G.U., B.Ç.; Data collection \&/or processing: G.U.; Analysis and/or interpretation: G.U., E.B., B.Ç.; Literature search: G.U., E.B., B.Ç.; Writing: G.U., E.B., B.Ç.; Critical review: E.B., B.Ç.

Conflict of Interest

None declared.

\section{REFERENCES}

1. Aouad MT, Nasr VG. Emergence Agitation in Children: An Update. Curr Opin Anaesthesiol 2005;18:614-9. [CrossRef]

2. Sikich N, Lerman J. Development and Psychometric Evaluation of The Pediatric Anesthesia Emergence Delirium Scale. Anesthesiology 2004;100:1138-45. [CrossRef]
3. Hino M, Mihara T, Miyazaki S, Hijikata T, Miwa T, GotO T, Ka K. Development and Validation of a Risk Scale for Emergence Agitation After General Anesthesia in Children: A Prospective Observational Study. Anesth Analg 2017;125:550-5. [CrossRef]

4. Berghmans JM, Poley M, Weber F, Van De Velde M, Adriaenssens P, Himpe JKD, et al. Does the Child Behavior Checklist predict levels of preoperative anxiety at anesthetic induction and postoperative emergence delirium? A prospective cohort study. Minerva Anestesiol 2015;81:145-56.

5. SonJS, Jang E, Oh MW, Leeji-Hye, HanYJ, Ko S. A comparison of postoperative emergence agitation between sevoflurane and thiopental anesthesia induction in pediatric patients. Korean J Anesthesiol 2015;68:373-8. [CrossRef]

6. Karayazılı R, Özkoçak I, Ayoğlu H, Yurtlu S, Okyay D, Hancı V. Comparison of the Effects of Oral Midazolam, Ketamine and Tramadol on Postoperative Agitation Related to Sevoflurane in Children [Article in Turskish]. Haseki Tip Bülteni 2010;48:146-52.

7. Ahrazoğlu MS, Türktan M, Özbek H, Güneş Y. Çocuklarda Şaşıllk Cerrahisinde Effects of Sevoflurane and Desflurane Anesthesia on Recovery and Agitation in Children Undergoing Strabismus Surgery. Ç.Ü. Tip Fakültesi Dergisi 2012;37:186-92.

8. WangW, Huang P, Gao W, Cao F, Yi M, Chen L, et al. Efficacy and Acceptability of Different Auxiliary Drugs in Pediatric Sevoflurane Anesthesia: A Network Meta-analysis of Mixed Treatment Comparisons. Sci Rep 2016;6:36553. [CrossRef]

9. Sezen Ö, Büyükkirli H, Bombaci E, Çolakoğlu S, Çevik B, Korkmaz Ş. Comparison of hemodynamic parameters and recovery characteristics of desflurane and propofol anaesthesia in children [Article in Turkish]. Göztepe Tip Dergisi 2006;21:116-20.

10. Guo J, Jin X, Wang H, Yu J, Zhou X, Cheng Y, et al. Emergence and recovery characteristics of five common anesthetics in pediatric anesthesia: a network meta-analysis. Mol Neurobiol 2017;54:4353-64.

11. Joo J, Lee S, Lee Y. Emergence delirium is related to the invasiveness of strabismus surgery in preschool-age children. J Int Med Res 2014;42:1311-22. [CrossRef]

12. Cyna AM, Middleton P. Caudal Epidural Block Versus Other Methods of Postoperative Pain Relief for Circumcision in Boys. Cochrane Database Syst Rev 2003:CD003005. [CrossRef]

13. Roberts AC, Shah-Becker S, O'Connell Ferster A, Baker A, Lauren E, Stahl LE, et al. Randomized Prospective Evaluation of Intraoperative Intravenous Acetaminophen in Pediatric Adenotonsillectomy. Otolaryngol Head Neck Surg 2018;158:368-74. [CrossRef]

14. Jung HJ, Kim JB, Im KS, Oh SH, Lee JM. Effect of ketamine versus thiopental sodium anesthetic induction and a small dose of fentanyl on emergence agitation after sevoflurane anesthesia in children undergoing brief ophthalmic surgery. Korean J Anesthesiol 2010;58:148-52. [CrossRef] 


\section{Pediyatrik Anestezi Uygulamalarında Derlenme Ajitasyonunu Etkileyen Faktörlerin Değerlendirilmesi}

Amaç: Çocuklarda anestezi sonrası derlenme döneminde görülen ajitasyon, çözülmesi zor bir sorun olup başarılı bir süreci sıkıntılı bir duruma dönüştürebilmektedir. Bu ileriye yönelik gözlemsel çalışmada; çocuklarda ameliyat sonrası ajitasyona neden olabilecek faktörleri belirlemek, böylece gelecekteki pediyatrik anestezi uygulamalarına ışık tutabilmek amaçlanmıştır.

Gereç ve Yöntem: Ortopedi ve travmatoloji, üroloji, göz hastalıkları, kulak burun boğaz hastalıkları ve baş boyun cerrahisi, çocuk cerrahisi, plastik ve rekonstrüktif cerrahi ameliyatları geçirecek, fizik durumu ASA I-II olan, 3-10 yaş arası 206 hasta çalışmamıza dahil edildi. Hastaların yaşı, cinsiyeti, açlık süresi, daha önce ameliyat geçirip geçirmediği, premedikasyon yapılıp yapılmadığı ve yapılmış ise ilaç ve uygulama şekli, indüksiyon tekniği ve indüksiyonda kullanılan ilaç, havayolu yönetiminin şekli, idamede kullanılan ilaçlar, anestezi süresi, ameliyat sonrası analjezi yönetimi, derlenme odası kalış süresi kaydedildi. Ayrıca tüm hastaların ameliyat sonrası I0. dakikada "Face, Legs, Activity, Cry, Consolability" (FLACC) Ağrıskoru, “Pediatric Anesthesia Emergence Delirium” (PAED) skoru, Modifiye Aldrete Skoru (MAS) değeri kaydedildi.

Bulgular: İstatistiksel değerlendirmede yaş, ameliyat tipi, premedikasyon, analjezi tekniği ve kullanılan ilaç, havayolu yönetimi, indüksiyonda ve idamede kullanılan ilaçlar ve anestezi süresinin ameliyat sonrası ajitasyonu anlamlı olarak etkilediği sonucu çıkmıştır $(p<0.05)$. Yapılan regresyon analizinde ise yaş, indüksiyonda kullanılan ilaç ve anestezi süresi derlenme dönemindeki ajitasyon için bağımsız risk faktörleri olarak saptanmıştır.

Sonuç: Çocuklarda anesteziden derlenirken görülen ajitasyonda etkilifaktörlerin başında çocuğun yaşı, anestezi süresi ve uygulanan anestezi indüksiyon tekniği gelmektedir. Yaş, cerrahi ve anestezi süresi değiştirilemeyen faktörler olduğuna göre uygulanacak anestezi indüksiyon tekniği anestezistin derlenme dönemindeki ajitasyonu kontrol etmede en önemli kozu olacaktır.

Anahtar Sözcükler: Anestezi; derlenme ajitasyonu; pediyatrik. 